\title{
Sentenças, rupturas, contradições. Provocações e problemas de interpretação a partir das relações e das perspectivas narrativas no Assim falava Zaratustra de Nietzsche*
}

\author{
Claus Zittel $^{* *}$
}

Resumo: As interpretações tradicionais de Assim falava Zaratustra tendem a menosprezar as implicações de sua forma literária. Este artigo realiza uma leitura atenta de passagens do livro que indicam que $\mathrm{o}$ aspecto literário e ficcional do texto de Nietzsche não pode ser desconsiderado, se se quiser alcançar uma compreensão mais aprofundada da obra e do estatuto de seus conceitos.

Palavras-chave: Zaratustra, ficção, literatura.

\footnotetext{
* Tradução de André Itaparica.

** Professor da Universidade de Stuttgart, Stuttgart, Alemanha.

Correio eletrônico: claus.zittel@ilw.uni-stuttgart.
} 
Em Aurora, publicado em 1881 e considerado numa carta como um comentário prévio ao Zaratustra, ${ }^{1}$ encontra-se um aforismo cujos tema e tom devem incomodar o leitor acostumado com o último escrito. Falo do aforismo de número 49, "O novo sentimento fundamental: nossa definitiva transitoriedade". Nele Nietzsche escreve:

- Antigamente buscava-se chegar ao sentimento da grandeza do homem apontando para a sua procedência divina: isso agora é um caminho interditado, pois à sua porta se acha o macaco, juntamente com outros animais terríveis, e arreganha sabidamente os dentes, como que a dizer: “Não prossigam nesta direção!". Então se experimenta agora a direção oposta: o caminho para onde vai a humanidade deve servir para provar sua grandeza e afinidade com Deus. Oh, tampouco isso resulta em algo! No final desse caminho se encontra a urna funerária do último homem e coveiro (...). Não importa o quanto a humanidade possa ter evoluído - e talvez ela esteja, no fim, ainda mais baixa do que no começo! - para ela não há transição para uma ordem mais alta, assim como a formiga e a lacrainha não podem, no final de sua "trajetória terrestre", alcançar o parentesco divino e a eternidade. $\mathrm{O}$ tornar-se arrasta atrás de si o haver sido: por que haveria uma exceção a esse eterno espetáculo, uma exceção para um pequeno astro e uma pequena espécie que o habita? Fora com tais sentimentalismos! (M/A 49. KSA 3.53).

Não é necessário folhear muito a primeira parte de Assim falava Zaratustra, publicada pouco depois, para se deparar, já no prólogo, com a célebre e muito citada passagem dos - assim parecem - discursos de Zaratustra, que, entre outras coisas, diz:

Eu vos ensino o além-do-homem. $\mathrm{O}$ homem é algo que deve ser superado. Que fizestes para superá-lo? Todos os seres, até agora, criaram algo acima

10 autor se refere a uma carta de Nietzsche a Franz Overbeck, de 7 de abril de 1884, na qual ele afirma: "Pela leitura de Aurora e A Gaia Ciência, achei, além disso, que quase não há uma linha que não possa servir de introdução, preparação e comentário ao mencionado Zaratustra. É um fato que eu fiz o comentário antes do texto" (KSB 6.496). Nota do tradutor.

30| Cad. Nietzsche, Guarulhos/Porto Seguro, v.39, n.2, p. 29-48, maio/agosto, 2018. 
Sentenças, rupturas, contradições. Provocações e problemas de...

de si próprios: e vós quereis ser a vazante dessa grande maré, e antes retroceder ao animal do que superar o homem? Que é o macaco para o homem? Uma risada, ou dolorosa vergonha. Exatamente isso deve o homem ser para o super-homem: uma risada, ou dolorosa vergonha. Fizestes o caminho do verme ao homem, e muito, em vós, ainda é verme. Outrora fostes macacos, e ainda agora o homem é mais macaco do que qualquer macaco. (...) Vede, eu vos ensino o além-do-homem! O além-do-homem é o sentido da terra. (...). $\mathrm{O}$ homem é uma corda atada entre o animal e o além-do-homem - uma corda sobre um abismo (Za/ZA, Prólogo, 3. KSA 4.14. Tradução modificada).

Como essas duas posições se relacionam entre si? Para quem quer escapar dessa gritante contradição interna nos textos citados, sem recorrer à observação frívola de que para cada afirmação de Nietzsche existe uma oposta, e levá-la a sério, como um problema, isto é, como uma tarefa de interpretação, há várias estratégias de escape à disposição, para simplificar o que foi exposto, como estas:

Em primeiro lugar, pode-se apontar para o fato de que Nietzsche atingiu uma outra fase de seu pensamento com o Zaratustra; mas, em termos sistemáticos, isso encontra uma dificuldade: a posição posterior pareceria um retrocesso para aquém do nível de reflexão anterior, ou, como no nosso exemplo, o desmascaramento psicológico da figura de pensamento posterior foi anteriormente tomado como ilusório e sentimental, e ainda por cima num escrito que, posteriormente, recebeu o estatuto de comentário.

Em segundo lugar, se poderia apontar para âmbitos textuais diferentes, nos quais se poderiam distinguir duas variantes principais: (a) No Zaratustra tudo é apenas poesia, ou seja, não é expresso em termos filosóficos estritos ou (b) No Zaratustra, como se trata de poesia, tudo é expresso de forma mais explícita, já que Nietzsche, escondido sob a máscara de Zaratustra, ousa dizer mais abertamente o que ele poderia apresentar de forma apenas alusiva. ${ }^{2}$ Aqui, a forma artística do texto ou é desvalorizada como não filosófica, ou, como na

2 Três vozes entre muitas: Gerhardt (2000); Himmelmann (2000); Simon (2000).

Cad. Nietzsche, Guarulhos/Porto Seguro, v.39, n.2, p. 29-48, maio/agosto, 2018. 
última variante, é vista como vestimenta exterior de pensamentos, frequentemente subjacentes, que Nietsche não teria tido coragem de falar de maneira aberta e explícita, ou seja, que, na poética de Zaratustra, a forma de expressão ${ }^{3}$ mais fácil e exotérica foi escolhida. Em terceiro lugar, pode-se insistir que o Zaratustra, ao contrário, oferece uma forma de exposição complexa, através da qual os pensamentos esotéricos se revelam, ou uma estrutura de complexas remissões internas que só podem ser formuladas como uma cadeia de diversas metáforas ${ }^{4}$. Com isso, assume-se uma posição contrária à tendência dominante na pesquisa Nietzsche, que é a de associar a poética primariamente a seu conteúdo expressivo, entendendo este como forma linguística exotérica, em vez de reconhecer, nos jogos de metáforas remissivos internos e, enquanto citações, também externos, um nível de comunicação também no âmbito estético. ${ }^{\mathbf{5}}$

Então seria o caso de investigar: quem diz, em que momento e de que maneira, isto e aquilo, no interior de Assim falava Zaratustra, como se desenvolvem as posições no decorrer da ação, como elas se relativizam umas em relação às outras, como elas aparecem enquanto formas, etc. Poder-se-ia constatar, primeiramente, que é a personagem ficcional de Zaratustra que apresenta, desde o início de um evento ficcional, determinadas doutrinas e que então depois retorna como que numa forma de autoparódia. Não é difícil perceber que escolho

3 Simon, 2000, p. 233;241.

4 Do mesmo modo, nas interpretações de Nietzsche, a exegese dos escritos publicados merece ter precedência metodológica. Essa máxima interpretativa, que soa evidente, é em grande medida desconsiderada por parte dos intérpretes de Nietzsche. Os textos póstumos possuem, em sua maioria, um caráter tético e dispensam, como via de regra, formatação estética. Com isso, contudo, prestamse a um grau de reflexão menor do que os formalmente acabados. As "doutrinas" prediletas de Nietzsche, como o "além-do-homem", a "vontade de potência" e o "eterno retorno" se "encontram" primordialmente nos póstumos e são destacadas ou descartadas em função da escolha feita.

5 Tais formas de leitura se fundam, via de regra, numa compreensão estética expressiva que está sob o signo de uma filosofia da vida. Em particular, a estética esboçada em $O$ nascimento da tragédia é sempre utilizada como chave de leitura do Zaratustra, sem atentar para a completa reviravolta que Nietzsche realiza em relação ao mundo valorativo de $O$ nascimento da tragédia.

32 | Cad. Nietzsche, Guarulhos/Porto Seguro, v.39, n.2, p. 29-48, maio/agosto, 2018. 
Sentenças, rupturas, contradições. Provocações e problemas de...

a última opção. ${ }^{6}$ Não se pode nunca deixar de frisar, diante também das publicações mais recentes, que Zaratustra não é o alter ego de Nietzsche, como Fausto não é o de Goethe ou Adrian Leverkühn não é o de Thomas Mann. Nietzsche é o autor de Assim falava Zaratustra, no qual muitas personagens aparecem, as quais se relacionam de forma complexa entre si; fazer de apenas uma dessas personagens um porta-voz de Nietzsche é simplesmente ignorar a elaboração estética do texto. $\mathrm{Na}$ interpretação filosófica tradicional da questão reina um ponto de vista fixado no conteúdo, que interpreta passagens do discurso isoladas do contexto, como se elas estivessem no interior de um tratado filosófico. Isso ocorre mesmo que retoricamente sempre se mencione o significado da estética para os textos de Nietzsche. No entanto, é comum que dessa menção não seja extraída nenhuma espécie de consequência para a interpretação.

Ao contrário. Eu sempre provoco forte desaprovação quando insisto, diante de intérpretes do Zaratustra, na artificialidade da arte. Em vastos círculos, particularmente da pesquisa Nietzsche, há um ressentimento manifesto para com o refinamento. Desprestigiados, vetustos docentes que se curvam, sentados em gabinetes com aquecimento central, martelando, no teclado de seus laptops: "Vivam de forma selvagem e perigosa", não gostam de ser incomodados, em sua exortação à incomunicabilidade dionisíaca, à ascensão do corpo (no texto), ou a uma filosofia da dança e da vida, por uma observação que defende que tudo isso é ficcional: vida esteticamente encenada, e que, também nessa encenação, é uma vida comprometida, questionadora e disruptiva.

6 Sobre isso, cf. Zittel (2000a). Aí são formulados também o contexto necessário e a base filosófica para as reflexões aqui colocadas, que se focam apenas numa face da problemática do Zaratustra. 
Zittel, C.

II

Retornando ao texto, trago para esclarecimento alguns poucos exemplos de provocações. "Zaratustra é ele mesmo o bufão que pula sobre pobres funâmbulos" (Nachlass/FP 16[88] do outono de 1883, KSA 10.531). Nesse fragmento, Nietzsche parece sugerir nada menos que Zaratustra, maliciosamente como o bufão, leva à morte os homens que querem se superar, e para isso aparece o funâmbulo, entre outros, nesse contexto imediato (com isso a contradição apontada no meu primeiro exemplo seria descartada pela forma dramática, pois a possibilidade vislumbrada de um desenvolvimento superior nada mais seria que uma manobra ilusória maliciosa, uma falsa promessa). Despertada a atenção, aparecem outras passagens que ganham um outro sentido ou ao menos um outro acento.

Já no prólogo Zaratustra havia avisado: "Para minha meta me ponho a caminho; pularei sobre os hesitantes e vagarosos. Assim, que minha marcha seja o seu declínio (Za/ZA, "Prólogo" 9, KSA 4.27). Zaratustra diz isso logo depois de o bufão ter gritado "como um demônio" e "saltado sobre aquele que lhe estava no caminho", deixando assim o funâmbulo despencar para a morte (Za/ZA, "Prólogo" 6, KSA 4.21). Agora, pode-se, passando pela metafórica do bufão, assim como pela metáfora contextual e do ator, reconhecer uma rede densamente urdida, que alinha todo o Zaratustra, e que, a partir da interpretação que se poderia extrair dela, coloca no centro a função agressiva e destruidora do procedimento literário (auto)parodístico. Aqui pretendo apenas indicar brevemente passagens em que Zaratustra diz de si mesmo o que ele seria: "um pescador de homens e bufão" (Za/ZA, "A oferenda do mel”, KSA 4.297), e melhor, "o mais malvado (...) pescador de homens (idem), que ri diante do "amor e da maldade" (Za/ZA, "A Saudação", KSA 4.348), que se dissimula com "a astúcia de seu discurso" (Za/ZA, "A oferenda do mel", KSA 4.296), que fala "cheio de graça e malícia" (Za/ZA, "O

34 Cad. Nietzsche, Guarulhos/Porto Seguro, v.39, n.2, p. 29-48, maio/agosto, 2018. 
Sentenças, rupturas, contradições. Provocações e problemas de...

feiticeiro", KSA 4.320). Quando cito aqui uma nota póstuma, não faço isso, de forma alguma, para proclamar que se deva interpretar o Zaratustra a partir dos póstumos. Ali se encontra uma ideia que, exatamente como ela está, pode ser comprovada no próprio texto. ${ }^{7}$ Por consequência, a personagem Zaratustra não deve ser interpretada essencialmente; ela remete uma forma a outra seguinte, e cada uma delas se torna instável.

No que diz respeito às formas dos papéis, pode-se observar uma função adicional, a saber, quando a personagem de Zaratustra assume um determinado papel, ele contraria suas próprias afirmações anteriores: por exemplo, quando Zaratustra proclama: "Zaratustra não deve se tornar pastor e cão de um rebanho!" (Za/ZA, "Prólogo", 9, KSA 4.25), "Não deverei ser pastor, nem coveiro" (idem, KSA 4.26); então depois ele sonha com um pastor, pergunta-se quem é esse pastor e enfim revela que seria ele mesmo (Za/ZA, "O convalescente", 2, $\mathrm{KSA} 4.273) .{ }^{8} \mathrm{Um}$ outra variante seria quando se pergunta sobre os comportamentos, algo como: confrontar a longa espera de Zaratustra pelo "meio-dia" com o desprezo, em diversos discursos, dessa atitude ("Infelizes também chamo aqueles que têm sempre de esperar". Za/ ZA, "Do espírito de gravidade", KSA 4.244). Ou se pense no mais feio dos homens, que se mete no papel de Zaratustra e que, contorcendose em seu estertor, se traveste no pensamento do eterno retorno.

\footnotetext{
7 Nessa questão fui mal-interpretado por Karl Pestalozzi, que, num belo ensaio, discorda de minha interpretação (Pestalozzi, 2001). Pestalozzi me acusa de ter querido autorizar minhas próprias afirmações como testemunhos de Nietzsche, que pertenceriam a outro contexto. Interesso-me apenas pela opção sistemática de uma outra interpretação, na qual eu possa mostrar que Nietzsche também já poderia tê-la em mente. A margem de manobra de interpretações possíveis deve ser ampliada, independentemente da interpretação a que Nietzsche tendia. Considero esta questão histórico-biográfica como frequentemente sem resposta e, em termos sistemáticos, desinteressante. Nas passagens problemáticas, fixo-me apenas na tomada de posição de Nietzsche pelo profetismo, que é justamente a menos fixa. Essa interpretação se sustentaria, por sua vez, apenas no apoio do lugar de profeta, sem questionar seu fraco fundamento. Só a união de muitos outros estudos sobre um conjunto de temas tornará minha interpretação, como espero, plausível.
}

8Cf. Pippin, 1988, p. 53.

Cad. Nietzsche, Guarulhos/Porto Seguro, v.39, n.2, p. 29-48, maio/agosto, 2018. 
Zittel, C.

Essas são algumas indicações de como Nietzsche suscita provocações que perturbam e destroem uma identificação imediata com o herói e que exigem do leitor atenção para com as contradições, rupturas, sinais de ironias, alusões duplicadas e citações ocultas ou formulações conjuntivas. Nietzsche sinaliza amiúde essa necessidade de diferenciação: “E, nesse caso, para apelar para a autoridade inestimável de Zaratustra: Zaratustra vai tão longe que afirma que "só acreditaria num Deus que soubesse dançar'[...]. Repetindo: quantos novos deuses ainda são possíveis! - Zaratustra mesmo é certamente apenas um velho ateu. Entenda-se bem! Embora Zaratustra diga que ele poderia acreditar, Zaratustra não pode acreditar" (Nachlass/FP 17[4] de maio-junho de 1888, KSA 13.526). Esse estatuto hipotético ou subjuntivo [konjunktivisch] fica particularmente claro, e por isso essas afirmações devem ser tomadas com reserva. Por exemplo, quando, no discurso central "Dos poetas", Zaratustra confessa aceitar a crítica platônica dos poetas, sendo também ele um poeta mendaz, ele está prontamente declarando, explicita e duplamente, sua própria visão do além-do-homem como uma mentira poética.

\section{III}

Consequentemente, afirmações singulares no interior do Zaratustra frequentemente ganham, por seu contexto narrativo, um decidido caráter ficcional. Assim, a passagem sobre o eterno retorno, no importante capítulo "Da visão e enigma”, se integra numa relação narrativa complexa, através da qual ela se divide, perspectivamente, em formas multifacetadas. Por exemplo, a apresentação nesse capítulo é narrativamente ficcional em vários níveis: (1) Aparece o narrador, que apresenta uma situação ficcional, de contos de fadas, num navio, e o silêncio de dias de Zaratustra; (2) Então essa situação é logo depois descrita como uma narrativa de viagem de aventura, na qual a tripulação do navio dá o seu melhor ("pois havia muita 
Sentenças, rupturas, contradições. Provocações e problemas de...

coisa estranha e perigosa a ouvir naquele barco, que vinha de longe e navegava para mais longe ainda" (Za/ZA, "Da visão e enigma", KSA 4.197); (3) Zaratustra, seduzido por essas histórias, começa ele próprio uma narrativa. Como sua própria narrativa é introduzida como um complemento a esse tipo de história, ela é marcada pelo tom fantasioso das histórias de marinheiro; (4) Zaratustra conta sobre uma "visão". Então segue-se um relato de uma visão onírica e nela ocorre uma disputa com o anão acerca do eterno retorno. Em seguida, (5) a discussão se encerra e, ainda no interior do sonho, introduzse uma reflexão de Zaratustra sobre seu monólogo; (6) De repente, desencadeadas pelo uivo de um cachorro, surgem em Zaratustra imagens de lembranças terríveis de sua infância, que o colocam em seguida (7) num estado em que ele não sabe mais se está acordado ou se sonha, tendo então a segunda visão, na qual ele vê um pastor, de cuja boca sai uma serpente.

A cena depois apresentada, com o pastor mordendo a serpente, foi normalmente interpretada como uma afirmação do eterno retorno. Mas acontece, como foi mostrado, que essa "afirmação" é apenas uma visão (1) que Zaratustra tem num sonho (2) que ele conta no navio na forma de um romance de aventura (3) e que, mais uma vez, foi integrada pelo narrador num conto de fadas.

\section{IV}

A seguir, investigarei um tipo particular e formalmente especial de provocações: as rupturas ficcionais no interior da perspectiva narrativa. Aqui, não Zaratustra, mas o próprio narrador falha em sua função. Pelo que sei, isso foi pouco observado na pesquisa até então, e apenas exegeses de Nietzsche orientadas pela filosofia do signo oferecem observações a respeito de Zaratustra, como o livro de Stegmaier. ${ }^{9}$ Antes de introduzir a análise da narrativa, deve-se ter

9 Cf. Stegmaier (1994). 
consciência de que não se deve colocar o procedimento artístico de Nietzsche em oposição a sua filosofia. Com o abandono das posições de $O$ nascimento da tragédia, Nietzsche não abandonou um paradigma substancialista apenas na filosofia, mas também em sua prática estética. Ele agora pensa de modo relacional, isto é, ele procede realizando remissões horizontais no nível dos signos, que produzem, repetidamente, como efeito, entidades ficcionais necessárias, que não podem ser fundadas positivamente. Essas remissões horizontais não são, contudo, de maneira alguma, restritas a relações entre conceitos ou relações entre metáforas e conceitos, já que ligam também metáforas em cadeias e constelações ${ }^{\mathbf{1 0}}$.

Para Nietzsche, agora as formas artísticas também recebem outra avaliação; elas não mostram mais, na linguagem simbólica, um significado próprio, oculto, mas um procedimento alegórico, e ainda só fazem isso como se, se comportando como se, houvesse um reino do verdadeiro cuja expressão seria a arte. Num texto-chave poético, Nietzsche explica isso utilizando o estilo barroco. Este surgiria

no desflorescer de toda grande arte, quando as exigências se tornaram grandes demais na arte de expressão clássica, como um evento natural que se presencia com tristeza - porque prenuncia a noite -, mas também com admiração pelos sucedâneos artísticos que lhes são próprios, na expressão e na narração. Entre eles está a escolha de materiais e temas de elevada tensão dramática, com os quais mesmo sem a arte o coração treme, já que céu e o inferno do sentimento se acham muito próximos; depois a eloquência dos afetos e gestos fortes (...) as luzes do crepúsculo, de transfiguração ou incêndio em formas tão acentuadas; e novas ousadias no meios e intenções (VM/OS 144, KSA 2.438).

Todos esses puros "sucedâneos artísticos na expressão e na narrativa" seriam, prossegue Nietzsche, para aqueles que fossem familiarizados com os procedimentos estéticos, facilmente reconhecíveis, "vigorosamente sublinhados de artista para artista,

10 Cf. Zittel, 2000b, p. 273-285.

38 | Cad. Nietzsche, Guarulhos/Porto Seguro, v.39, n.2, p. 29-48, maio/agosto, 2018. 
Sentenças, rupturas, contradições. Provocações e problemas de...

enquanto o leigo não pode senão imaginar que enxerga o contínuo e involuntário transbordar das cornucópias de uma primordial arte da natureza" (VM/OS 144, KSA 2.438).

Apenas da perspectiva exotérica do leigo essa arte parecerá imediatamente viva, enquanto o especialista em arte a compreenderá como encenação retórica de uma vitalidade que sempre surge quando a arte já está em decadência. No meu estudo sobre o Zaratustra, ${ }^{11}$ tentei complementar a tese não desenvolvida adequadamente aqui de que o Zaratustra de Nietzsche corresponde, no seu procedimento, a essas e outras características do estilo barroco e, por isso, enquanto forma em si mesma, torna visível o prejuízo sofrido pela metafísica.

Isso se mostra claramente, entre outras coisas, pelo manejo nietzschiano da forma narrativa: em Assim falava Zaratustra, a destruição de ilusões, através das passagens épicas que introduzem os discursos, é frequente. Eu poderia mostrar, com alguns poucos exemplos, por meio da investigação da atitude narrativa de Nietzsche, como é rico em consequências para a interpretação do Zaratustra seguir indicações autorreflexivas dispersas e passagens-chave primorosas.

Uma ruptura ficcional particularmente marcante ocorre na passagem do "O canto notívago", na qual o narrador subitamente se dirige aos leitores no tom de um contador de história infantil: "E o que vocês acham que aconteceu naquele instante?" (Za/ZA, "O canto notívago", KSA 4.396. Tradução modificada). ${ }^{12}$ Depois disso, o narrador se distancia ainda mais de seu relato e acrescenta diligentemente: "como alguns contadores acham". Como se ele tivesse com isso a impressão de objetividade, porque senão sua exposição provocaria uma impressão ilusória e, ainda como se já

11 Zittel (2000a).

12 Igualmente, já no capítulo "O mais feio dos homens": "- Mas depois de ouvir essas palavras - que acham que aconteceu na alma de Zaratustra?” (Za/ZA, “O mais feio dos homens”, KSA 4.328. Tradução modificada). 
não fosse suficiente, ele acrescenta: "Seja como tenha sido, tenha ou não dançado o asno nessa noite, o fato é que então ocorreram prodígios maiores e mais raros que uma dança de asno. Em suma, como diz a máxima de Zaratustra: que importa?" (Za/ZA, "O canto notívago", KSA 4.396).

Na versão prévia dessa passagem, dizia-se, contudo: “Seja como tenha sido - na verdade nem todos que ouviram a história de Zaratustra acreditam nela". ${ }^{13}$ No parágrafo seguinte, o narrador inicia: "e quem poderia imaginar que pensamentos lhe andavam então na alma?" (Za/ZA, "O canto notívago", KSA 4.397). Essa ruptura ficcional é o ponto alto de um crescente distanciamento do narrador do evento, que é indicado como um todo na quarta parte, já com o acréscimo das partes épicas e enfim com a alocução "e o que acham" claramente destacada. Além disso, as expressões de distanciamento se multiplicam na quarta parte, como "visivelmente". A passagem citada por último, por exemplo, continua assim: "Mas visivelmente seu espírito o deixava, voava à frente, pairava longe, achava-se, por assim dizer, 'em elevado cume', como está escrito, 'entre dois mares', - vagando entre passado e futuro como pesada nuvem". ${ }^{14}$

A indicação que é citada, "como está escrito", remete, paradoxalmente, na forma de uma citação expressamente marcada, ao início de "Os sete selos", da terceira parte. Enquanto a história é contada, seu narrador faz como se fosse um relato sobre episódios da vida anterior de seu protagonista, baseados em fontes históricas. O texto se esclarece a si mesmo como lenda e esclarece, ainda, que ele mesmo esclarece isso, isto é, faz notar suas técnicas ficcionais, declarando-se literatura. Com isso se abre um abismo entre o texto escrito e o Zaratustra que fala, que despreza a escrita (Za/ZA, "Do ler

$13 \mathrm{KGW}, \mathrm{VI} / 4,787$. Essa narrativa, mantida em tom de conto de fadas e ainda disruptiva, introduz o ponto alto da festa na caverna, onde Zaratustra, junto com os homens superiores, canta a "canção da meia-noite"!

14 Cf. Za/ZA, "O canto notívago", KSA 4.308; 333.

40| Cad. Nietzsche, Guarulhos/Porto Seguro, v.39, n.2, p. 29-48, maio/agosto, 2018. 
Sentenças, rupturas, contradições. Provocações e problemas de...

e escrever", KSA 4.48). A ação narrada retroage a uma longa distância e é apresentada como dependente de testemunhas tradicionais, em cuja existência o leitor, contudo, nunca pode acreditar, já que Nietzsche e seu narrador não se esforçam em emprestar à narrativa a aparência de verdade histórica. Aliás, ela não foi citada de uma compilação histórica, mas do próprio livro. Ao contrário, o narrador se coloca, enquanto ele cita a si mesmo, como leitor e compilador histórico. Assim ele pode, nessa passagem, quando lembramos o discurso anterior, ter sido levado por um fingimento explícito. $\mathrm{Ou}$, generalizando: a ficção histórica introduzida se destroça. $\mathrm{O}$ que é consequente, já que antes a posição de narrador onisciente é deixada de lado com o "como alguns contadores acham". Mas, à medida que ele, em todo o caso, se revela como leitor de seu próprio texto, essa relação abriga ainda um ponto particular que ele, apesar do anátema anterior de Zaratustra contra todo leitor, realiza: “Quem conhece o leitor nada mais faz pelo leitor. Mais um século de leitores - e até o espírito federá. Que todo mundo possa aprender a ler, a longo prazo isso estraga não só a escrita, mas também o pensamento" (Za/ZA, "Do ler e escrever", KSA 4.48). Correto? Mas acontece também, como já se sabe, o veredicto anterior de Zaratustra no interior da própria narrativa.

Leitores esforçados são, como explicitam muitas citações, exteriores ao narrador, assim como ao autor Nietzsche e ao próprio Zaratustra, que, de sua parte, reúne, de todas as leituras, o material de seus discursos, e que, além disso, "desse caminho recolheu a palavra "além-do-homem" (Za/ZA, "Das velhas e novas tábuas", KSA 4.248).

Ao todo, não há muitas passagens como essa, o que pode explicar por que elas foram até então ignoradas, quase sem exceção, por intérpretes que abertamente se deixaram arrebatar pela história. ${ }^{\mathbf{1 5}}$

15 Apenas Stegmaier (1994), aponta que, com o comentário "como muitos contadores acham", a tradição da história se "torna expressamente questionável”. Cf. Stegmaier (2009). 
Mas qualquer uma delas, individualmente, já é suficientemente significativa, e elas são no conjunto de grande relevância para a avaliação correta da atitude e da estrutura narrativa e assim da consciência ficcional de Assim falava Zaratustra. Por isso citamos a mais importante delas: na primeira vez, o leitor pode ficar perplexo no fim do quinto parágrafo do prólogo: "E aqui findou o primeiro discurso de Zaratustra, que é chamado de "prólogo" (Za/ZA, KSA $4.20)$.

O prólogo de Assim falava Zaratustra não está, contudo, no fim. Nietzsche produz aqui uma insegurança provocativa:

- Em primeiro lugar, ele se refere a um "sujeito indeterminado" ["man"] ficcional, que não é mais explicado, da mesma forma como o próprio narrador volta a desaparecer por muito tempo, do campo de visão do leitor.

- Em segundo lugar, ele provoca insegurança, ao interromper de repente a situação da narração, até então objetiva e direta, através da interpolação de um narrador autoral, e com isso coloca todo o evento numa nova perspectiva, mas essa nova perspectiva não se estabiliza e é logo abandonada. Imediatamente depois de um novo desaparecimento do narrador autoral, é retomada a forma de narrativa posta em questão por ele, na qual, contudo, não se pode mais confiar.

- Em terceiro lugar, ele provoca quando o narrador declara o primeiro discurso de Zaratustra como prólogo e assim deixa minar, com a designação, o próprio início do livro de Nietzsche e o torna metarreflexivo. De repente, o narrador parece ter o livro de Nietzsche já diante de si para poder citá-lo como fonte.

Declarações que determinam gêneros são introduzidas a partir de um metanível, também em partes posteriores. Por exemplo: "e este é o relato da conversa de Zaratustra com o cão de fogo" (Za/ZA, "Dos grandes acontecimentos", KSA 4.168), ou: "Ninguém me conta 
Sentenças, rupturas, contradições. Provocações e problemas de...

algo novo: assim, conto-me a mim mesmo" (Za/ZA, "Das velhas e novas tábuas", KSA 4.246). ${ }^{\mathbf{1 6}}$

Outros sinais muito claros que indicam ao leitor que ele deve refletir sobre as condições de narração e da atitude narrativa são introduzidos na quarta parte: "Este foi o início daquela longa refeição que nos livros de histórias é chamada 'a última ceia'. Mas nela não se falou de outra coisa a não ser o homem superior" (Za/ ZA, "A última ceia", 4.355). Esse é o fim do capítulo que no Assim falava Zaratustra tem como título "A última ceia”. Aqui Nietzsche confunde, propositadamente, as referências, fala de muitos livros de história, joga com a narrativa bíblica da última ceia e deixa-as se imiscuírem. Isso é tudo menos um diagnóstico sem importância. No entanto, essa passagem conduz ao discurso seguinte "do homem superior" e, pela narrativa, coloca as mensagens contidas ali, desde o início, sob sinais de suspeita.

Agora gostaria de indicar um outro modo como o narrador pode perder seu papel, no que diz respeito não à lógica narrativa, mas à forma narrativa.

Já havia comentado que o mais feio dos homens travestia relações. Quando ele finalmente, na terceira tentativa de estertorar, pode murmurar o pensamento do eterno retorno $(\mathrm{Za} / \mathrm{ZA}$, "O canto notívago", KSA 4.398), seus gestos se tornam, com a múltipla repetição da cena, cada vez mais constrangedores; tanto que, diante do primeiro estertor e gorgolejo do mais feio dos homens, Zaratustra espelha seu próprio comportamento anterior numa imagem menos lisonjeira, desfigurada até o grotesco: "algo saía do chão, gorgolejando e estertorando como a água gorgoleja e estertora ao passar, à noite, por canos obstruídos" (Za/ ZA, "O mais feio dos homens", KSA 4.328).

Esta é uma das poucas passagens em que a ilusão narrativa, que se abriga os eventos num espaço fantasioso, histórica e localmente indeterminado, é rompida com uma comparação provinda do mundo do

16 Sobre as provocações da designação "Prólogo", ver também, mais recentemente: Villwock, 2001, p. 5. 
dia a dia; vê-se o autor Nietzsche, como ele está num quarto de hotel e ouve o barulho da descarga, - o que auxilia o efeito surpreendente que essa comparação sarcástica, por seu mau gosto, já provoca. ${ }^{17}$

Poder-se-ia conceder que talvez outras categorias de organização sejam estáveis para isso, relações numéricas ou formas de gêneros, por exemplo. Manfred Rauh apontou, na estrutura do Zaratustra, do início ao fim, cenários de cavernas. ${ }^{18}$ Se se observar a simetria que Rauh sugere através das metáforas de cavernas, então se encontram algumas provocações ricas em consequências. No início do quarto livro, Zaratustra está em sua caverna, assim como no último capítulo. Lá, além disso, é repetido todo o início do texto do "prólogo", o que parece produzir uma tensa simetria especular. Pois esse capítulo é, em si, da mesma forma simétrico, já que a passagem inicial é repetida no final quase literalmente: "Assim falou Zaratustra, e deixou sua caverna, ardente e forte como o sol matinal que surge por trás de escuras montanhas" (Za/ZA, "O sinal", KSA 4.408). A organização não podia ser melhor. Contudo, o que diz a última passagem? Zaratustra abandona sua caverna? Mas ele já está do lado de fora! ${ }^{19}$ Subitamente se cria uma perplexidade. A ordem simétrica conduz a uma contradição com a lógica da ação. A lógica de encadeamento e a ordem sincrônica estão em oposição,

17 Que um otimismo resoluto pode ser interpretado como a mais aguda careta do desespero é algo apresentado em: Bennholdt-Thomsen (1974), p. 187. Ela interpreta positivamente o gorgolejo do mais feio dos homens, assim como os últimos homens em geral: "Quando esse homem, no fim, é capaz de falar livremente e afirmar sua vida, então o espírito de gravidade, em certa medida, aceitouse e superou-se. $\mathrm{O}$ conhecimento e a vitória de Zaratustra são aqui internalizados pelo mais feio dos homens como algo próprio. (...). As palavras do mais feio dos homens e o que ela possibilita, ou seja, sua capacidade de falar, objetivam, num certo sentido, o processo de conscientização de Zaratustra, ao mesmo tempo que apresentam seu primeiro êxito.

18 Rauh (1961), p. 55-72.

19 Essa contradição só foi percebida, até onde sei, por Blumenberg (1989), p. 624.

44 | Cad. Nietzsche, Guarulhos/Porto Seguro, v.39, n.2, p. 29-48, maio/agosto, 2018. 
Sentenças, rupturas, contradições. Provocações e problemas de...

com a consequência de que não se pode mais manter nem uma nem outra sem entrar em contradição. Então se torna necessário interpretar metaforicamente a caverna. Sua imagem flui de simples ponto geográfico para metáfora do interior de Zaratustra ou talvez da filosofia de Zaratustra. ${ }^{20}$ A ordem, aparentemente fixa, se dissolveu e sucumbe a uma estrutura muito mais móvel. As metáforas logo se afastam da fixação provisória através de estruturas externas e formais e constituem sua própria constelação. Olhando com atenção o início do último capítulo, pode-se ler com mais acuidade e perceber que as provocações se multiplicam lá:

Na manhã após essa noite, porém, Zaratustra saltou de seu leito, cingiu os lombos e deixou sua caverna, ardente e forte como o sol matinal que surge por trás de escuras montanhas. "Ó grande astro", falou ele, como outrora havia falado, "ó profundo olho da felicidade, que seria de toda a tua felicidade, se não tivesses aqueles que iluminas?" (Za/ZA, "O sinal", KSA 4.405).

A princípio, pensa-se que é uma reprise do início, então se lê: "- Isso falou Zaratustra ao seu coração, quando o sol nascia: então olhou (...)" (idem). Diferentemente do início de Assim falava Zaratustra, nada é dito diretamente ao sol, mas é Zaratustra que agora, ele mesmo, é como um sol. Ele fala apenas para si mesmo e de forma absurda no escuro, pois só depois - quando se pode ler que "o sol nasceu" - é que o sol nasce! A simetria que está aí se mostra justamente como diferença. E também a metáfora do sol se torna de repente polissêmica, justamente onde não se esperava, pelo chamamento direto, cujo receptor, supostamente unívoco, se desfaz, parecendo que Zaratustra se dirige a si mesmo. Essas provocações se produzem a partir de um modelo similar, presente em todo o discurso;

20 A caverna como metáfora do mundo interior pode ser provada, por exemplo, em JGB/BM 289; como metáfora da filosofia, em KSB 8.206. 
por exemplo, ele diz logo depois, expressamente, que Zaratustra fechou os olhos, e logo "diante dele clareou" e ele viu "o sinal".

\section{VI}

Em geral, pode-se tentar, como sugestão de interpretação desse procedimento, admitir que, com Zaratustra, em oposição ao próprio entendimento poético que reivindica ter inventado, junto com a despedida da tradição, uma linguagem nova e mais verdadeira, se está diante de um outro caso exemplar: com ele, não apenas uma tradição filosófica chega, tematicamente, ao seu fim, como exposição do declínio dos valores por causa da morte de Deus, mas, ao mesmo tempo, torna-se claro que com isso também perecem as pressuposições sob as quais até então algo poderia ser narrado. A forma de narrativa, disruptiva, anti-orgânica, faz ver em si mesma as consequências do prejuízo sofrido. A narrativa organiza-se no seu próprio processo de declínio diagnosticado. Junto a isso, torna-se claro que, no Zaratustra, se fez uso de um maciço procedimento estético que pode ser designado igualmente de formas tardias reativas-reflexivas de apresentação artística, quais sejam: paródias e particularmente autoparódias, travestimentos, sarcasmos, pastiches, ironias, quebras de ilusões, montagens, citações excessivas, ficções conscientes (por exemplo, explicitação do estatuto de fábula), situações narrativas complexas e confusas ou rupturas na atitude narrativa.

A forma de escrita de Nietzsche em Assim falava Zaratustra contraria a pretensão de que, na estrutura de uma narrativa, experiências e ideias possam ser realizadas e transmitidas positivamente através do meio da ficção literária. Não se chega mais a essa realização, seja de conteúdo ou de forma, a não ser que seja na mentira, e é essa a nova experiência. $O$ fracasso na tentativa de realização se torna agora princípio de ação, que pode chegar a um término [Ende], mas nunca a uma meta [Ziel], que se esgota paulatinamente depois de 
Sentenças, rupturas, contradições. Provocações e problemas de...

cada pretensa partida e finalmente sucumbe forçosamente no final aporético da quarta parte.

\begin{abstract}
Traditional interpretations of Thus spoke Zarathustra tend to pay little attention to the implications of its literary form. This paper undertakes a close reading of Zarathustra's passages that point out that the literary and fictional aspect of Nietzsche's text cannot be put aside, if one pursues a better understanding of the work as well as of the status of its concepts.
\end{abstract}

Keywords: Zarathustra, fiction, literature.

\title{
Referências bibliográficas
}

BENNHOLDT-THOMSEN, A. Nietzsches Also sprach Zarathustra als literarisches Phänomen. Frankfurt/Main: Athenau-Verlag, 1974.

BLUMENBERG, H. Höhlenausgänge. Frankfurt am Main: Suhrkamp, 1989.

GERHARDT, V. (2000). "Die Erfindung eines Weisen”. In: GERHARDT, V. Friedrich Nietzsche. Also sprach Zarathustra. Berlin: Akademie Verlag, 2000.

HIMMELMANN, Beatrix, “Zarathustras Weg”. In: GERHARDT, V. Friedrich Nietzsche. Also sprach Zarathustra. Berlin: Akademie Verlag, 2000.

NIETZSCHE, F. Assim falou Zaratustra. Tradução: Paulo César Souza. São Paulo: Companhia das Letras, 2011.

NIETZSCHE, F. Aurora. Tradução: Paulo César Souza. São Paulo: Companhia das Letras, 2004.

NIETZSCHE, F. Humano, demasiado humano II. Tradução: Paulo César Souza. São Paulo: Companhia das Letras, 2008.

NIETZSCHE, F. Sämtliche Briefe: Kritische Studienausgabe (KSA) Berlim/Munique: Walter de Gruyter/ dtv, 1988.

NIETZSCHE, F. Sämtliche Werke: Kritische Studienausgabe (KSA) Berlim/Munique: Walter de Gruyter/ dtv, 1988. 
Zittel, C.

NIETZSCHE, F. Werke: Kritische Gesamtausgabe. Berlim: Walter de Gruyter, 1967-.

PESTALOZZI, K. "Zarathustras prophetische Reden im Kontext der Epoche". In: VILLWOCK, P. (Org.). Nietzsches „Also sprach Zarathustra”, Basel 2001.

PIPPIN, Robert B. "Irony and Affirmation in Nietzsche's Thus spoke Zarathustra". In: GILLESPIE, Michael A. \& STRONG,T. B. (Orgs.). Nietzsche's new seas, Chicago 1988.

RAUH, M. "Die Einsamkeit Zarathustras". In: Zeitschrift für Religion und Geistesgeschichte 21 (1961).

SIMON, J. "Ein Text wie Nietzsches Zarathustra". In: GERHARDT, V. Friedrich Nietzsche. Also sprach Zarathustra. Berlin: Akademir Verlag, 2000.

STEGMAIER, W. "Antidoutrinas. Cena e em Assim falava Zaratustra, de Nietzsche". Tradução: Clademir Araldi. In: Cadernos Nietzsche (25), 2009.

STEGMAIER, W. Nietzsches Genealogie der Moral. Darmstadt: Wissenschaftliche Buchgesellschaft, 1994.

VILLWOCK, P. (Org.), Nietzsches „Also sprach Zarathustra, 5 ff. Basel: Schwabe, 2001.

ZITTEL, C. "Die Aufhebung der Anschauung im Spiel der Metapher. Nietzsches relationale Semantik". In: Nietzscheforschung, (7), 2000b.

ZITTEL, C. Das ästhetische Kalkiul von Friedrich Nietzsches Also sprach Zarathustra. Würzburg: Königshausen \& Neumann, 2000a.

Artigo recebido para publicação em 14/04/2018 Artigo aceito para publicação em 14/07/2018

$48 \mid$ Cad. Nietzsche, Guarulhos/Porto Seguro, v.39, n.2, p. 29-48, maio/agosto, 2018. 